\title{
Haemolysis with Björk-Shiley and Starr-Edwards prosthetic heart valves: a comparative study
}

\author{
S. D. SLATER, I. A. SALLAM, W. H. B A IN, \\ M. A. TUR NER, and T. D. V. L A W R IE \\ Departments of Haematology, Cardiovascular Surgery and Cardiology, \\ The Royal Infirmary, Glasgow
}

\begin{abstract}
Slater, S. D., Sallam, I. A., Bain, W. H., Turner, M. A., and Lawrie, T. D. V. (1974): Thorax, 29, 624-632. Haemolysis with Björk-Shiley and Starr-Edwards prosthetic heart valves: a comparative study. A comparison was made of the haemolytic complications in 85 patients with two different types of Starr-Edwards cloth-covered ball and cage prosthesis with those in 44 patients with the Björk-Shiley tilting disc valve. Intravascular haemolysis, as detected by the presence of haemosiderinuria, occurred significantly less often with the Björk-Shiley than with the Starr-Edwards valve, the overall incidence with aortic, mitral or multiple replacements being $31 \%, 15 \%$, and $20 \%$ for Björk-Shiley and $94 \%, 92 \%$, and $88 \%$ for Starr-Edwards valves respectively. There was no significant difference in the frequency of haemolysis between each of the two types of StarrEdwards prosthesis studied at either the aortic (2300 versus 2310 model) or mitral (6300 versus 6310$)$ site.

Haemolytic anaemia developed in only one patient with a Björk-Shiley valve but was common though usually mild with Starr-Edwards prostheses, particularly aortic valve replacements with the 2300 model and in aortic plus mitral ( \pm tricuspid) replacements. The greater severity of haemolysis produced by Starr-Edwards valves, again especially of the latter types, was further demonstrated by higher serum lactate dehydrogenase and 24-hour urinary iron levels.

It is concluded that the Björk-Shiley tilting disc valve represents a significant advance in the amelioration of the haemolytic complications of prosthetic valves.
\end{abstract}

Some degree of intravascular haemolysis is common with many types of cardiac valve prosthesis (Marsh and Lewis, 1969). The ball and cage type developed by Starr and Edwards is probably the most widely used (Braunwald and Detmer, 1968), and its frequent association with haemolysis, more marked with aortic valve replacements, is well documented (Yacoub and Keeling, 1968; Myhre and Rasmussen, 1969; Walsh, Starr, and Ritzmann, 1969). A consequent anaemia, though not uncommon, is infrequently a serious complication (Kastor et al., 1968; Rodgers and Sabiston, 1969; Slater and Fell, 1972).

The Björk-Shiley tilting disc prosthesis was introduced clinically by Björk in 1969 (Björk, 1969). This comprises a plastic or pyrolytic carbon disc which is suspended and pivots between two support legs attached to the valve ring. The distinctive haemodynamic features of this arrangement as compared with the central occluding ball-valve type are that it allows a more central and laminar flow of blood and produces over aortic valves a smaller systolic peak pressure gradient (Björk, o 1970). Our experience demonstrates a consider- N ably reduced frequency and severity of haemolysis $N$ in patients with Björk-Shiley prostheses compared to those with different types of Starr-Edwards cloth-covered ball and cage valves.

\section{PATIENTS AND METHODS}

The 127 patients studied had their operations performed at the cardiac surgery unit, Glasgow Royal $\stackrel{\mathbb{D}}{\Omega}$ Infirmary. They are divided into two groups. Those $\mathbb{D}$ with Björk-Shiley tilting disc valves (18 men and $26 \frac{2}{\sigma}$ 
women; mean age 44, range 21-66 years) and those with ball and cage Starr-Edwards prostheses (37 men and 48 women; mean age 42 , range $27-55$ years). A total of 129 cases were finally investigated since StarrEdwards valves in two patients required replacement with Björk-Shiley prostheses. The aortic (A) and mitral (M) Starr-Edwards valves were all of the Teflon-covered metal cage and stellite metal ball type, either models 2300 (A) and 6300 (M) or models 2310 (A) and 6310/6320 (M) which have a wider orifice and in which the cloth on the valve ring is protected by metal studs ('composite seat' prostheses). StarrEdwards tricuspid valve replacements were the lowprofile non-tilting disc models 6500 (metal disc) or 6520 (plastic disc). The distribution in the patients of the type and site of valve replacement is detailed in Table I.

Full haematological values were determined using the Coulter Counter Model 'S'. Blood film examinations and reticulocyte counts were performed by standard methods (Dacie and Lewis, 1968). Urine was examined for haemosiderin, and urinary iron excretion was estimated as described by Slater and Fell (1972). Serum lactate dehydrogenase levels were assayed on the LKB 8600 Reaction Rate Analyser at $37^{\circ} \mathrm{C}$ using the Boehringer test combination kit (normally not $>525 \mathrm{iu} / \mathrm{l})$. The criterion for the diagnosis of intravascular haemolysis was the presence of persistent haemosiderinuria. Anaemia was defined as a haemoglobin of less than $13.5 \mathrm{~g} / 100 \mathrm{ml}$ with a packed cell volume of less than $40 \%$ in the male, the corresponding values for the female being $11.5 \mathrm{~g} / 100 \mathrm{ml}$ and $35 \%$ (Dacie and Lewis, 1968). Haemolytic anaemia (uncompensated haemolysis) was diagnosed when anaemia occurred on at least two consecutive occasions in the presence of haemosiderinuria and red cell fragmentation and in the absence of any other unrelated precipitating cause.

T A B L E I

DETAILS OF PROSTHETIC VALVE TYPE IN 127 PATIENTS

\begin{tabular}{|c|c|c|}
\hline $\begin{array}{c}\text { Valve } \\
\text { Replaced } \\
\text { (No. of cases) }\end{array}$ & $\begin{array}{|cc|}\text { Starr-Edwards (S-E) } \\
\text { Ball and Cage Models } \\
\text { 2300(A) } & 2310(\mathrm{~A}) \\
\text { 6300(M) } & \text { 6310(M) }\end{array}$ & $\begin{array}{l}\text { Björk-Shiley (B-S) } \\
\text { Tilting Disc Models }\end{array}$ \\
\hline $\begin{array}{l}\text { Aortic (48) } \\
\text { Mitral (49) }\end{array}$ & $\begin{array}{ll}15 & 17 \\
21 & 15^{3}\end{array}$ & $\begin{array}{l}16 \\
13\end{array}$ \\
\hline $\begin{array}{l}\text { Aortic plus } \\
\text { mitral (16) } \\
\text { Aortic plus mitral } \\
\text { plus tricuspid (4) } \\
\text { Mitral plus } \\
\text { tricuspid (12) }\end{array}$ & $\begin{array}{r}10^{4} \\
1^{5} \\
6^{6}\end{array}$ & $\begin{array}{l}6 \\
3 \\
6\end{array}$ \\
\hline
\end{tabular}

${ }^{1}$ Total cases $=129$ since two of the 127 patients studied required reoperation with a different valve type (a 2300 replaced by a B-S (A); a 6310 replaced by a B-S (M)).

'A=aortic; $M=$ mitral; $S-E$ tricuspid valve replacements $(T)$ are described in the text.

'Two of these 15 patients had a 6320 (M) model.

'Comprises a $2300+6300$ (5 cases); a $2300+6310$ (1 case); a $2310+$ 6300 ( 1 case); a $2310+6320$ ( 2 cases); and a $2310+6520$ (M) (1 case). Comprises a $2300+6300+6500$ (T)

Comprises a $6300+6500$ (T) (1 case); a $6310+6520$ (T) (4 cases); and a $6320+B-S$ (T) (1 case).
These investigations were begun three to 12 months after operation in $70 \%$ of cases and 12 to 24 months in a further $22 \%$. Tests were repeated in most cases at three- to six-monthly intervals and more frequently when indicated. The eventual period of post-operative follow-up in $87 \%$ of cases varied from one to five years. This variation was determined principally by the type of prosthesis, as the use of the Starr-Edwards 2300 and 6300 series antedated the 2310 and 6310 models, and the Björk-Shiley valves were the most recently employed.

Statistical analysis was carried out by the $\chi^{2}$ method for the comparison of frequency distributions, and by Student's $t$ tests for the comparison of mean values between groups (Bailey, 1959).

\section{RESULTS}

INCIDENCE OF HAEMOLYSIS AND HAEMOLYTIC ANAEMIA The incidence of haemolysis, compensated and uncompensated, is detailed in Table II according to valve type and site.

Comparison between valve types Haemolysis was much less frequent with Björk-Shiley aortic or mitral valves compared to either of the corresponding Starr-Edwards prostheses $(P<0.005)$. Since the proportion of aortic plus mitral ( \pm tricuspid) replacements to mitral plus tricuspid replacements is very similar in the Starr-Edwards and BjörkShiley groups they are combined for statistical purposes, a much lower incidence of haemolysis with Björk-Shiley multiple replacements being evident $(P<0.001)$. Only one case of haemolytic anaemia developed with Björk-Shiley valves and this was transient and mild.

A comparison between each of the two types of Starr-Edwards valve at either the aortic or mitral position shows no difference in the high incidence of haemolysis. However, haemolytic anaemia has developed more often with the 2300 aortic valve than with the 2310 model, although the difference does not reach conventional levels of significance in the numbers studied $\left(\chi^{2}=3.07,0.1>\mathrm{P}>0.05\right)$.

Comparison between valve sites There has proved to be no significant difference in the incidence of haemolysis between aortic and mitral replacements, between patients with aortic prostheses and those with aortic plus mitral ( \pm tricuspid) prostheses, or between mitral and mitral plus tricuspid replacements, comparisons being made between equivalent valve types. Nonetheless haemolysis has been more severe with the aortic 2300 valve than with the mitral 6300 , as evidenced by a greater incidence of haemolytic anaemia $(0.005>P>0.001)$ as well as by higher levels of serum lactate dehydrogenase and urinary iron 
T A B LE I I

INCIDENCE OF HAEMOLYSIS, COMPENSATED AND UNCOMPENSATED, ACCORDING TO PROSTHETIC VALVE TYPE AND SITE

\begin{tabular}{|c|c|c|c|c|}
\hline \multirow{2}{*}{$\begin{array}{c}\text { Valve } \\
\text { Replaced }\end{array}$} & \multirow{2}{*}{$\begin{array}{c}\text { Prosthesis } \\
\text { Model } \\
\text { (No. of cases) }\end{array}$} & \multirow{2}{*}{$\begin{array}{l}\text { Patients without } \\
\text { Haemolysis }\end{array}$} & \multicolumn{2}{|c|}{ Patients with Haemolysis } \\
\hline & & & Compensated & Uncompensated \\
\hline Aortic & $\begin{array}{l}2300(15) \\
2310(17) \\
\text { B-S (16) }\end{array}$ & $\begin{array}{r}2 \overline{(12 \%)} \\
11(69 \%)\end{array}$ & $\begin{array}{r}5(33 \%) \\
10(59 \%) \\
4(25 \%)\end{array}$ & $\begin{array}{r}10(67 \%) \\
5(29 \%) \\
1(6 \%)\end{array}$ \\
\hline Mitral & $\begin{array}{l}6300(21) \\
6310 / 20(15) \\
\mathrm{B}-\mathrm{S} \quad(13)\end{array}$ & $\begin{array}{r}3(14 \%) \\
11(85 \%)\end{array}$ & $\begin{array}{r}16(76 \%) \\
11(73 \%) \\
2(15 \%)\end{array}$ & $\begin{array}{l}2(10 \%) \\
4(27 \%) \\
-\end{array}$ \\
\hline $\begin{array}{r}\text { Aortic +mitral } \\
( \pm \text { tricuspid })\end{array}$ & $\begin{array}{l}\text { S-E (11) } \\
\text { B-S ( 9) }\end{array}$ & $\begin{array}{c}- \\
6(67 \%)\end{array}$ & $\begin{array}{l}5(45 \%) \\
3(33 \%)\end{array}$ & $\begin{array}{c}6(55 \%) \\
-\end{array}$ \\
\hline Mitral + tricuspid & $\begin{array}{ll}\text { S-E } & (6) \\
\text { B-S } & (6)\end{array}$ & $\begin{array}{l}2(33 \%) \\
6(100 \%)\end{array}$ & $3(50 \%)$ & $1(17 \%)$ \\
\hline
\end{tabular}

B-S = Björk-Shiley; S-E = Starr-Edwards.

(see below). It has been equally severe with StarrEdwards aortic plus mitral ( \pm tricuspid) valves. There were, however, no significant differences in the lesser degrees of haemolysis as determined by these parameters between the 2310 aortic and $6310 / 20$ mitral valves, or between the BjörkShiley aortic and mitral valves.

HAEMOGLOBIN LEVELS AND RETICULOCYTE COUNTS Details of the haemoglobin and reticulocyte counts are given in Table III. The values recorded are the means ( \pm SD) of the lowest haemoglobins and highest reticulocyte counts observed in the patients during the periods of follow-up.

The striking differences in results lie between patients with either type of Starr-Edwards aortic valve and those with Björk-Shiley aortic valves, and between Starr-Edwards and Björk-Shiley aortic plus mitral ( \pm tricuspid) valves, those with Björk-Shiley prostheses having the higher haemoglobin values and lower reticulocyte counts
$(\mathrm{P}<0.01)$. The values with the 2310 Starr-Edwards aortic valves occupy an intermediate position, although while reticulocyte counts are significantly lower in comparison with the 2300 prostheses $(0.01>P>0.005)$, the difference in haemoglobin levels is not statistically significant in the numbers studied. The greater haemolysis with the aortic 2300 valve compared to the 6300 mitral is again apparent from the differences in haemoglobin $(0.1>\mathrm{P}>0.05)$ and reticulocyte count $(0.01>\mathrm{P}>0.005)$, and although there is a marginal absence of statistical significance in respect of the haemoglobin values, this almost certainly conceals a real clinical difference when the disparate sex distribution between the two groups is considered.

SERUM LACTATE DEHYDROGENASE (LDH) LEVELS The results of LDH estimations are shown in Fig. 1 and include the highest recorded levels in cases where repeated estimations have been performed.

T A B L E I I I

HAEMOGLOBIN AND RETICULOCYTE LEVELS ACCORDING TO PROSTHETIC VALVE TYPE AND SITE

\begin{tabular}{|c|c|c|c|c|c|}
\hline \multirow[t]{2}{*}{$\begin{array}{c}\text { Valve } \\
\text { Replaced }\end{array}$} & \multirow{2}{*}{$\begin{array}{c}\begin{array}{c}\text { Prosthesis } \\
\text { Model } \\
\text { (no. and sex of } \\
\text { cases) }\end{array} \\
\end{array}$} & \multicolumn{2}{|c|}{$\begin{array}{c}\text { Haemoglobin } \\
(\mathrm{g} / 100 \mathrm{ml})\end{array}$} & \multicolumn{2}{|c|}{$\begin{array}{c}\text { Reticulocytes } \\
(\%)\end{array}$} \\
\hline & & Mean & SD & Mean & SD \\
\hline Aortic & $\begin{array}{l}2300(12 \mathrm{M}, 3 \mathrm{~F}) \\
2310(12 \mathrm{M}, 5 \mathrm{~F}) \\
\mathrm{B}-\mathrm{S}(12 \mathrm{M}, 4 \mathrm{~F})\end{array}$ & $\begin{array}{l}11 \cdot 8 \\
13 \cdot 1 \\
14 \cdot 8\end{array}$ & $\begin{array}{l}2.9 \\
1.6 \\
1.5\end{array}$ & $\begin{array}{l}9 \cdot 7 \\
3 \cdot 7 \\
2 \cdot 1 \\
\end{array}$ & $\begin{array}{l}8 \cdot 1 \\
2 \cdot 2 \\
1 \cdot 1 \\
\end{array}$ \\
\hline Mitral & $\begin{array}{l}6300(4 \mathrm{M}, 17 \mathrm{~F}) \\
6310 / 20(7 \mathrm{M}, 8 \mathrm{~F}) \\
\mathrm{B}-\mathrm{S}(2 \mathrm{M}, 11 \mathrm{~F})\end{array}$ & $\begin{array}{l}13 \cdot 4 \\
13 \cdot 1 \\
14 \cdot 3\end{array}$ & $\begin{array}{l}2 \cdot 0 \\
1 \cdot 2 \\
1 \cdot 4\end{array}$ & $\begin{array}{l}3 \cdot 3 \\
4 \cdot 6 \\
2 \cdot 4\end{array}$ & $\begin{array}{l}2 \cdot 1 \\
2 \cdot 3 \\
1 \cdot 2\end{array}$ \\
\hline $\begin{array}{l}\text { Aortic }+ \text { mitral } \\
(: \pm \text { tricuspid })\end{array}$ & $\begin{array}{ll}\text { S-E } & (1 \mathrm{M}, 10 \mathrm{~F}) \\
\text { B-S } & (2 \mathrm{M}, 7 \mathrm{~F}) \\
\end{array}$ & $\begin{array}{l}11 \cdot 2 \\
13 \cdot 8\end{array}$ & $\begin{array}{l}1 \cdot 8 \\
0.9\end{array}$ & $\begin{array}{l}7 \cdot 6 \\
2 \cdot 2\end{array}$ & $\begin{array}{l}5 \cdot 0 \\
1 \cdot 1\end{array}$ \\
\hline Mitral + tricuspid & $\begin{array}{ll}\text { S-E } & (1 M, 5 F) \\
\text { B-S } & (2 M, 4 F)\end{array}$ & $\begin{array}{l}12.9 \\
13.9\end{array}$ & $\begin{array}{l}1.3 \\
0.8\end{array}$ & $\begin{array}{l}3 \cdot 0 \\
2 \cdot 8\end{array}$ & $\begin{array}{l}1.9 \\
1.2\end{array}$ \\
\hline
\end{tabular}

B-S = Björk-Shiley; S-E = Starr-Edwards. 


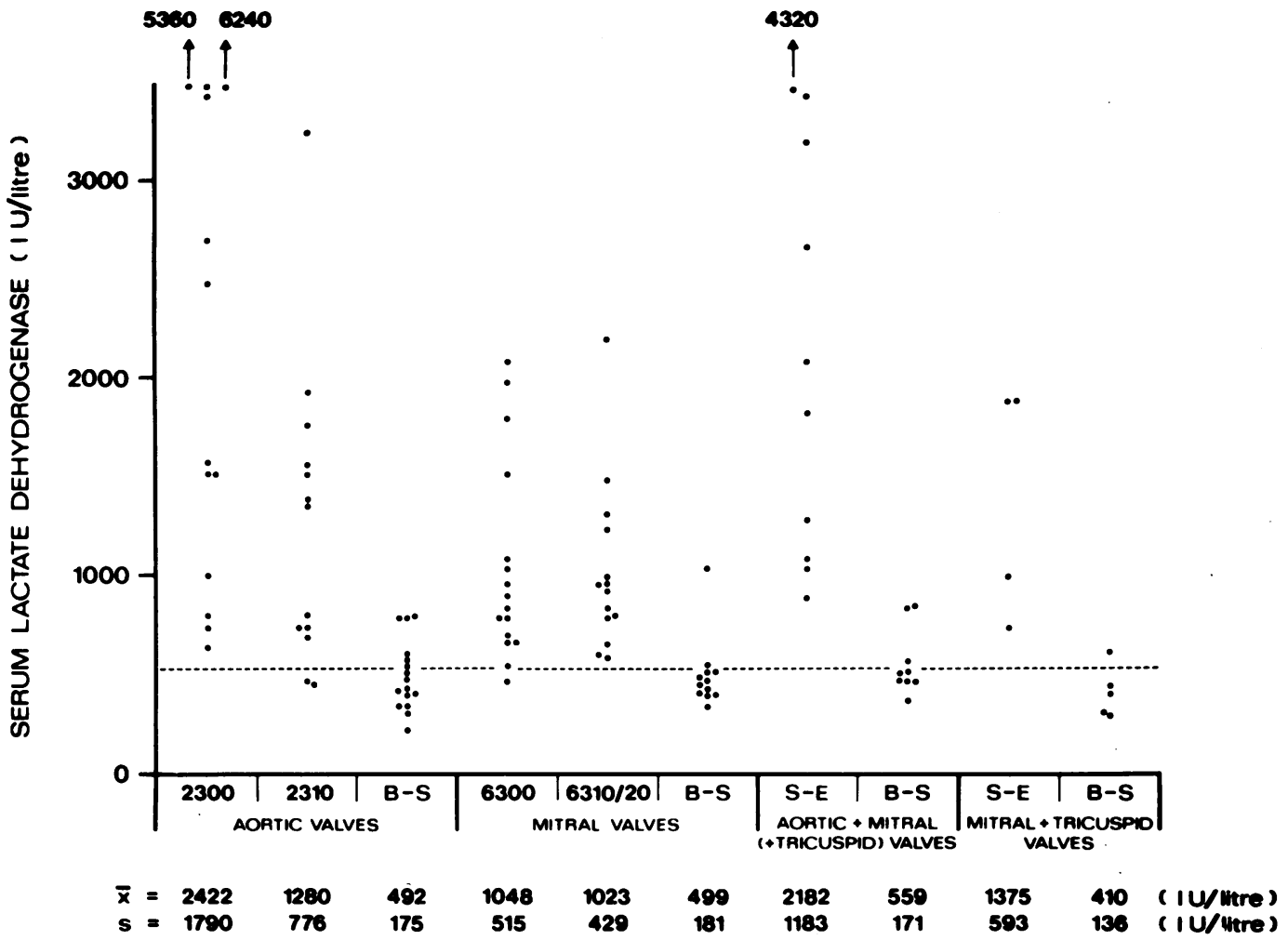

FIG. 1. Serum lactate dehydrogenase levels according to prosthetic valve type and site $(S-E=S t a r r-E d w a r d s$; $B-S=B j o ̈ r k-S h i l e y ;$ mean $(\bar{x})$ and standard deviation $(s)$ values are given; interrupted line $=$ upper limit of normal).

A very close association was observed between an elevated LDH level and the presence of haemosiderinuria, and between a normal LDH level and the absence of haemosiderinuria, there being agreement in all but six of the 112 cases in which parallel results were available $(P<0.001)$. It follows that the frequency distribution of abnormal LDH levels for different valve types and sites is almost the same as for the incidence of haemolysis as defined by the presence of haemosiderinuria. Thus LDH levels were usually normal with Björk-Shiley valves but nearly always elevated in patients with Starr-Edwards valves. There are, however, differences in the magnitude of $\mathrm{LDH}$ elevations with Starr-Edwards prostheses, the mean level with aortic 2300 valves being significantly higher than that with the 2310 aortic valves $(0.05>P>0.025)$ or the 6300 mitral valves $(0.02>P>0.01)$. Serum LDH levels were equally high in patients with Starr-Edwards aortic plus mitral ( \pm tricuspid) prostheses.
URINARY IRON EXCRETION The results of estimation of urinary iron output are shown in Fig. 2. There was a significant association between an increased measured urinary iron output and the presence of haemosiderinuria, and between a normal urinary iron excretion and the absence of haemosiderinuria $(\mathrm{P}<0.001)$. Therefore, as with serum LDH levels, the incidence of raised urinary iron levels closely parallels the incidence of haemolysis (haemosiderinuria), being low with Björk-Shiley valves and high with Starr-Edwards valves. There is also a greater amount of urinary iron excreted in patients with Starr-Edwards 2300 aortic valves than in those with 2310 valves $(0.05>P>0.025)$, 6300 mitral valves $(0.005>P>0.001)$, or StarrEdwards aortic plus mitral ( \pm tricuspid) valves $(0.05>P>0.02)$. A comparison of the latter, which includes patients with 2300 and 2310 aortic valves, with the combined group of Starr-Edwards single aortic valve replacements $(2300+2310)$ shows no significant difference. 


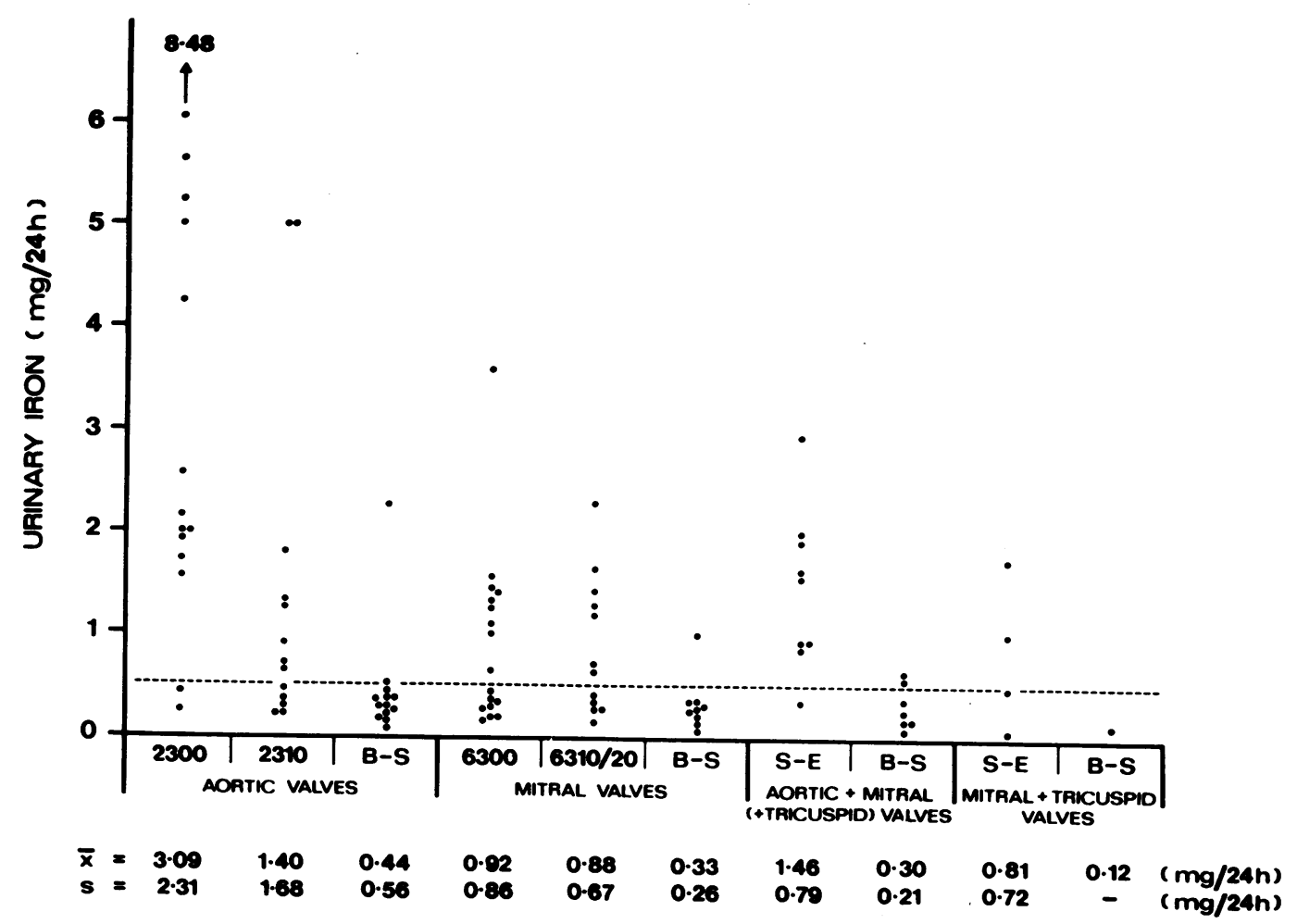

FIG. 2. Urinary iron excretion according to prosthetic valve type and site $(S-E=S t a r r-E d w a r d s ; B-S=$ Björk-Shiley; mean $(\bar{x})$ and standard deviation $(s)$ values are given; interrupted line $=$ upper limit of normal).

\section{DISCUSSION}

Persistent haemosiderinuria is a reliable and almost diagnostic sign of chronic intravascular haemolysis (Crosby and Dameshek, 1951; Dacie, 1960). It has therefore been used as the criterion for the diagnosis of haemolysis in this study. The investigation also has the advantage of being easily applied on a repetitive basis to large numbers of patients. Serum lactate dehydrogenase (LDH) levels were also estimated since not only are high values a sensitive, if not so specific, indication of active intravascular haemolysis (Andersen, Gabrieli, and Zizzi, 1965; Jorgensen, Zimmerman, and Wang, 1967), but the extent of the elevation correlates well with the severity of haemolysis as determined by the survival of chromium-51 $\left({ }^{51} \mathrm{Cr}\right.$ )-labelled red cells (Walsh et al., 1969; Myhre, Rasmussen, and Andersen, 1970). Where anaemia developed its haemolytic nature was substantiated in all cases by the concomitant presence of red cell fragmentation, high reticulocyte counts, marked haemosiderinuria, and, measured in most cases, reduced ${ }^{51} \mathrm{Cr}$ ery- throcyte survival, as well as by the exclusion of any other unrelated precipitating cause of $\underset{x}{\tilde{D}}$ anaemia.

The results show the very common occurrence of haemolysis after valve replacement with a $\dot{\delta}$ metal ball and cloth-covered cage Starr-Edwards $₹$ prosthesis and demonstrate an equally high inci- o dence of haemolysis with either, aortic, mitral or multiple replacement $(94 \%, 92 \%$, and $88 \%$ of cases respectively). Furthermore, no significant $\mathrm{N}$ difference was found in the frequency of haemoly- $\sigma$ sis between the two types of Starr-Edwards pros- $N$ theses studied, the earlier 2300 aortic and $6300 \mathrm{~N}$ mitral valves compared to the corresponding 2310 응 and 6310/20 models. By contrast, haemolysis 6 appears to be a relatively uncommon complication $\stackrel{\varnothing}{\Phi}$ of the Björk-Shiley tilting disc prosthesis at any $\stackrel{\mathcal{D}}{+}$ site, occurring in $31 \%$ of aortic, $15 \%$ of mitral, 0 and $20 \%$ of multiple replacements respectively, the differences in frequency between the sites not being of statistical significance in the numbers studied. 
The severity of haemolysis was also much greater with Starr-Edwards than with Björk-Shiley prostheses, as evidenced by the more common occurrence of haemolytic anaemia, the lower haemoglobin levels, and the higher reticulocyte and LDH levels. Haemolysis was particularly marked with the Starr-Edwards 2300 aortic valve, anaemia occurring in 10 out of 15 patients, whereas only one case of haemolytic anaemia developed with Björk-Shiley valves, an aortic replacement, and this was transient and mild. The degree of haemolysis, if not its frequency, was also related to valve site, being more severe with the 2300 aortic than with the 6300 mitral valve, and equally severe with Starr-Edwards aortic plus mitral ( \pm tricuspid) replacements. There were, however, no significant differences in the lesser degrees of haemolysis between the 2310 aortic and $6310 / 20$ mitral valves, or between the BjörkShiley aortic and mitral valves.

The incidence of haemolytic anaemia in this study is greater than the $<5-15 \%$ incidence previously reported (Kastor et al., 1968; Myhre and Rasmussen, 1969; Rodgers and Sabiston, 1969; Walsh et al., 1969), but this is probably due to differences in the types of prostheses studied and to imprecise differences in the definition of anaemia. We have accepted as anaemic all cases with haemoglobin and packed cell volume levels consistently below the lower limit of normal according to sex, as defined by Dacie and Lewis (1968). More recent studies have shown similar high figures for the incidence of haemolytic anaemia with cloth-covered Starr-Edwards valves (Eyster, Rothchild, and Mychajliw, 1971; Crexells et al., 1972). Nonetheless, in nearly all cases in this study $(25 / 29)$ the anaemia has been mild (Hb 9.0 $+\mathrm{g} / 100 \mathrm{ml}$ ), and in the remaining few the haemoglobin has fallen between 7.0 and $9.0 \mathrm{~g} / 100$ $\mathrm{ml}$. In 11 patients the anaemia has resolved in association with oral iron; in another 11 patients a recurrent or continuous mild anaemia has persisted; and in four (mild) cases no further followup is yet available. Only three patients, all with aortic cloth-covered prostheses, have required operation because of resistant severe anaemia. In one of these (with a 2300 model) the valve orifice was found to be lined by pale (? fibrinous) deposits; in another (2300) the cloth on the cage struts was badly worn and shredded; and in the third (2310) there was severe regurgitation. It should be stressed, therefore, that despite the high incidence of haemolysis and haemolytic anaemia, the clinical outcome following operation in the majority of the patients with Starr-
Edwards prostheses has been very satisfactory. A positive correlation has been reported between the measured urinary iron excretion and the degree of haemosiderinuria (Slater and Fell, 1972), which in turn bears a direct approximate relationship to the severity of intravascular haemolysis (Crosby and Dameshek, 1951; Slater and Fell, 1972). In this study the high urinary iron losses with Starr-Edwards prostheses, especially the aortic 2300 valve, further reflect therefore the greater degree of haemolysis with them in comparison to the Björk-Shiley valves with which the measured urinary iron output was usually within normal limits. The practical significance also of excess urinary iron excretion is that this may lead to iron deficiency and precipitate or aggravate anaemia in patients with chronic intravascular haemolysis (Sears et al., 1966; Walsh et al., 1966; Reynolds, Coltman, and Beller, 1967; Walsh et al., 1969). Twelve of the anaemic patients in this study had obvious blood film and/ or serum evidence of iron deficiency. Treatment with iron may allow the establishment of a compensated haemolytic state, and it has also been recommended as a routine prophylactic measure in the presence of persistent appreciable haemosiderinuria (Slater and Fell, 1972). On the basis of these results it would appear generally unnecessary to prescribe prophylactic iron supplements to patients with Björk-Shiley valves.

The almost constant presence of haemolysis with Starr-Edwards aortic cloth-covered valves is well recognized (Walsh et al., 1969; Myhre, Dale, and Rasmussen, 1970; Eyster et al., 1971). Crexells et al. (1972) have demonstrated, as in this study, the equally high incidence of haemolysis irrespective of valve site. These reports have dealt mainly with the earlier 2300 aortic and 6300 mitral valves, and it has been suggested that the particularly common occurrence of haemolysis with them is related to increased shearing stresses set up by raised pressure gradients over the valves, as a consequence partly of a restriction in the final orifice diameter due to Teflon covering of the valve ring (Kloster, Herr, Starr, and Griswold, 1969; Reis et al., 1970; Eyster et al., 1971). Certainly there is evidence of a greater degree of haemolysis in aortic valves with smaller orifices (Myhre et al., 1970; Crexells et al., 1972). In this study the incidence of anaemia was significantly higher in patients who had smaller aortic prostheses. This mechanism would be aggravated by any further reduction in orifice diameter by tissue ingrowth or thrombotic deposits (Reis et al., 1970), and such a sequence of events may have been responsible 
for the severe haemolytic anaemia in one patient in this study.

Red cells may be damaged by non-endothelialized portions of Teflon or by the stellite metal ball (Myhre et ál., 1970; Crexells et al., 1972). Furthermore, as with another patient in this study, marked wearing of the cloth-covering of the cage struts or valve seating has been reported to cause severe haemolysis (Reis et al., 1970; Boruchow, Ramsey, and Wheat, 1971; Santinga, Kirsh, and Batsakis, 1973). Lesser degrees of cloth damage may be instrumental in the frequent development of mild haemolysis in cloth-covered prostheses, perhaps by trapping of the red cells within the interstices of the cloth or between the cloth and the underlying metal, rendering them vulnerable to direct trauma from the ball, or by forced contact of the cells with bare Tefion fibres. This would be analogous to the red cell fragmentation and distortion produced by intravascular fibrin strands in conditions causing microangiopathic haemolytic anaemia (Bull, Rubenberg, Dacie, and Brain, 1968). All these possible factors are likely to be accentuated in the high pressure system of the aortic valve and, whereas initial experience with prosthetic valves suggested that severe haemolysis was unlikely to develop in the absence of significant aortic regurgitation, it is becoming clear that as much attention should be paid to the evaluation of systolic murmurs in this area.

The 2310 aortic and 6310/6320 Starr-Edwards valves were constructed with a wider orifice to mitigate against pressure gradient factors (Kloster et al., 1970; Winter et al., 1972). In addition, the small metal studs that protrude through the cloth on the valve ring and constitute the seat for the ball ('composite seat') also protect the cloth on the ring from wear. The results in this study suggest that, while this modification has not reduced the incidence of haemolysis in comparison with the 2300 and 6300 valves, the severity of haemolysis with the aortic prosthesis is less, and other workers appear to have had similar experience (Crexells et al., 1972; Santinga et al., 1973).

In comparison with the haemolytic properties of either of the Starr-Edwards cloth-covered valves at any site the results demonstrate a striking advantage in patients with a Björk-Shiley prosthesis. There appears to have been little detailed published study of its haemolytic properties, though they have been reported as minimal and without clinical significance (Björk, Olin, and Rodriguez, 1972). Good clinical and experimental haemodynamic results are well documented (Björk, 1969 and 1970; Messmer, Okies, Hallman, and Cooley, 1971; Olin, 1971; Björk et al., 1972; $\overline{0}$ Turner et al., 1974).

The infrequent and mild haemolysis encountered $\frac{\bar{F}}{\overline{\frac{N}{}}}$ in patients with these valves is likely to be related $\stackrel{\mathbb{\Omega}}{\Omega}$ to the absence of high pressure gradients due to the large orifice area and the central flow design, $\overrightarrow{ }$ and to a reduction in turbulence because of the? more laminar flow allowed by this design. The $\vec{\omega}$ disc does not overlap the valve seating and has a low closing velocity, and therefore any direct $\overrightarrow{\vec{x}}$ trauma to red cells between opposing surfaces isi largely avoided compared to the ball and cage arrangement. Furthermore, apart from the outer o sewing ring of Teflon there is no cloth incor- $\triangle$ porated in the model. Experimental studies have? demonstrated that the flow characteristics in Björk-Shiley prostheses produce a low energy loss $Z$ across the valve, which is accompanied by a minimal degree of haemolysis, in comparison to the $\frac{}{3}$ high energy loss and greater degree of haemolysis with the cloth-covered Starr-Edwards valves $\overrightarrow{\overrightarrow{0}}$ (Sallam, 1973).

The duration of postoperative follow-up in patients with Björk-Shiley valves has not been as long as that in patients with Starr-Edwards clothcovered prostheses. In virtually all of the Starr-o Edwards valve patients in this study haemolysis was already demonstrable at the time of the first $\stackrel{\perp}{\circ}$ detailed postoperative investigations, which in $\overrightarrow{\overrightarrow{0}}$ most cases took place within three to 12 months 3 of operation and within a further 12 months in nearly all of the remainder. Of the 28 patients? who developed haemolytic anaemia, 12 did so within the first three to 12 postoperative months, 을 and 10 within the second 12 months. Since most of the Björk-Shiley valve patients have been $\frac{\dot{\sigma}}{3}$ followed up for one to two years after operation. the comparison of haemolysis between them and 0 the patients with Starr-Edwards valves is considered appropriate and valid.

It is concluded that the Björk-Shiley tilting disc $>$ valve represents a significant advance in the amelioration of the haemolytic complications of $\bar{N}$ prosthetic valves.

We should like to acknowledge the interest in this study of Dr. G. A. McDonald, and also the help of the technical staff of the Department of Haematology. We are grateful also to Dr. M. J. McQueen of the Department of Pathological Biochemistry for his $\stackrel{\infty}{\mathbb{D}}$ assistance.

\section{REFERENCES}

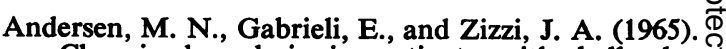
Chronic hemolysis in patients with ball-valve $\frac{}{\mathbb{D}}$ prostheses. Journal of Thoracic and Cardio- $\varrho$ vascular Surgery, 50, 501. 
Bailey, N. T. J. (1959). Statistical Methods in Biology, pp. 47-61. English Universities Press, London.

Björk, V. O. (1969). A new tilting disc valve prosthesis. Scandinavian Journal of Thoracic and Cardiovascular Surgery, 3, 1.

(1970). A new central-flow tilting disc valve prosthesis: one year's clinical experience with 103 patients. Journal of Thoracic and Cardiovascular Surgery, 60, 355.

- Olin, C., and Rodriguez, L. (1972). Comparative results of aortic valve replacement with different prosthetic heart valves. Journal of Cardiovascular Surgery, 13, 268.

Boruchow, I. B., Ramsey, H. W., and Wheat, M. W. Jr. (1971). Complications following destruction of the cloth covering of a Starr-Edwards aortic valve prosthesis. Journal of Thoracic and Cardiovascular Surgery, 62, 290.

Braunwald, N. S. and Detmer, D. E. (1968). A critical analysis of the status of prosthetic valves and homografts. Progress in Cardiovascular Diseases, 11, 113 .

Bull, B. S., Rubenberg, M. L., Dacie, J. V., and Brain, M. C. (1968). Microangiopathic haemolytic anaemia: mechanisms of red-cell fragmentation: in vitro studies. British Journal of Haematology, 14, 643.

Crexells, C., Aerichide, N., Bonny, Y., Lepage, G., and Campeau, L. (1972). Factors influencing hemolysis in valve prosthesis. American Heart Journal, 84, 161.

Crosby, W. H. and Dameshek, W. (1951). The significance of hemoglobinemia and associated hemosiderinuria, with particular reference to various types of hemolytic anemia. Journal of Laboratory and Clinical Medicine, 38, 829.

Dacie, J. V. (1960). The Haemolytic Anaemias, Part I, 2nd edition. Churchill, London.

- and Lewis, S. M. (1968). Practical Haematology, 4th edition. Churchill, London.

Eyster, E., Rothchild, J., and Mychajliw, O. (1971). Chronic intravascular hemolysis after aortic valve replacement: long-term study comparing different types of ball-valve prostheses. Circulation, 44, 657.

Jorgensen, C. R., Zimmerman, T. S., and Wang, Y. (1967). Serum lactate dehydrogenase elevation in ambulatory cardiac patients: evidence for chronic hemolysis. Circulation, 35, 79.

Kastor, J. A., Akbarian, M., Buckley, M. J., Dinsmore, R. E., Sanders, C. A., Scannell, J. G., and Austen, W. G. (1968). Paravalvular leaks and hemolytic anemia following insertion of StarrEdwards aortic and mitral valves. Journal of Thoracic and Cardiovascular Surgery, 56, 279.

Kloster, F. E., Farrehi, C., Mourdjinis, A., Hodam, R. P., Starr, A., and Griswold, H. E. (1970). Hemodynamic studies in patients with clothcovered composite-seat Starr-Edwards valve prostheses. Journal of Thoracic and Cardiovascular Surgery, 60, 879.

Herr, R. H., Starr, A., and Griswold, H. E. (1969). Hemodynamic evaluation of a cloth- covered Starr-Edwards valve prosthesis. Circulation, 39, Supplement 1, p. 119.

Marsh, G. W. and Lewis, S. M. (1969). Cardiac haemolytic anaemia. Seminars in Hematology, 6, 133.

Messmer, B. J., Okies, J. E., Hallman, G. L., and Cooley, D. A. (1971). Mitral valve replacement with the Björk-Shiley tilting-disc prosthesis. Journal of Thoracic and Cardiovascular Surgery, 62, 938.

Myhre, E., Dale, J., and Rasmussen, K. (1970). Erythrocyte destruction in different types of Starr-Edwards aortic ball valves. Circulation, 42, 515.

and Rasmussen, K. (1969). Mechanical haemolysis in aortic valvular disease and aortic ballvalve prosthesis. Acta Medica Scandinavica, 186, 543.

, and Andersen, A. (1970). Serum lactic dehydrogenase activity in patients with prosthetic heart valves: a parameter of intravascular hemolysis. American Heart Journal, 80, 463.

Olin, C. (1971). Pulsatile flow studies of prosthetic aortic valves. Scandinavian Journal of Thoracic and Cardiovascular Surgery, $5,1$.

Reis, R. L., Glancy, D. L., O'Brien, K., Epstein, S. E., and Morrow, A. G. (1970). Clinical and hemodynamic assessments of fabric-covered Starr-Edwards prosthetic valves. Journal of Thoracic and Cardiovascular Surgery, 59, 84.

Reynolds, R. D., Coltman, C. A., and Beller, B. M. (1967). Iron treatment in sideropenic intravascular hemolysis due to insufficiency of Starr-Edwards valve prostheses. Annals of Internal Medicine, 66, 659.

Rodgers, B. M. and Sabiston, D. C. (1969). Hemolytic anemia following prosthetic valve replacement. Circulation, 39, Supplement 1, p. 155.

Sallam, I. A. (1973). Experimental evaluation of mechanical haemolysis with cardiac valve prostheses. Ph.D. Thesis, University of Glasgow.

Santinga, J. T., Kirsh, M. M., and Batsakis, J. T. (1973). Hemolysis in different series of the StarrEdwards aortic valve prostheses. Chest, 63, 905.

Sears, D. A., Anderson, P. R., Foy, A. L., Williams, H. L., and Crosby, W. H. (1966). Urinary iron excretion and renal metabolism of hemoglobin in hemolytic diseases. Blood, 28, 708.

Slater, S. D. and Fell, G. S. (1972). Intravascular haemolysis and urinary iron losses after replacement of heart valves by a prosthesis. Clinical Science, 42, 545.

Turner, M. A., Bain, W. H., Thomson, R. M., Fife, R., Lawrie, T. D. V., and Lorimer, A. R. (1974). Early results of heart valve replacement using the Björk-Shiley prosthesis. Scandinavian Journal of Thoracic and Cardiovascular Surgery (in press).

Walsh, J. R., Brodeur, M. T. H., Ritzmann, L. W., Sutherland, D. W., and Starr, A. (1966). Urinary iron excretion in patients with prosthetic heart valves. Journal of the American Medical Association, 198, 505. 
Starr, A., and Ritzmann, L. W. (1969). Intravascular hemolysis in patients with prosthetic valves and valvular heart disease. Circulation, 39, Supplement 1, p. 135.

Winter, T. Q., Reis, R. L., Glancy, D. L., Roberts, W. C., Epstein, S. E., and Morrow, A. G. (1972). Current status of the Starr-Edwards clothcovered prosthetic cardiac valves. Circulation, 45, Supplement 1, p. 14.
Yacoub, M. H. and Keeling, D. H. (1968). Chronico haemolysis following insertion of ball valve prostheses. British Heart Journal, 30, 676.

Requests for reprints to: Dr. S. D. Slater, Department of Medicine, Southern General Hospital, Glasgow. 